\title{
Individualised versus institutional religion: Is there a mediating position?
}

The significance of religious individualisation is broadly accepted by scholars focusing on Western Europe in the twentieth century. For the most part, however, analyses have focused on the dichotomy of individualised versus institutionalised religion. Individualised religion usually tends to ignore, rather than reject outright, the authority and truth claims raised by institutional religion, whereas institutional religion tends to be critical of the completely subjective nature of individualised religion. This paper asks if academic theology can play a mediating role between the two extremes. The present paper sketches a possible approach, limiting its perspective to contemporary Christianity in Germany and using this as a case study. It starts from the assumption that faith and doubt are intimately connected with the shaping and reshaping of personal identity. Religious beliefs and practices have to "resonate" with the individual, but claims of intersubjective rationality and the possibility for truth can still be maintained.

\section{Religious individualisation in contemporary German Christianity - again?}

If there is any field of study in the sociology of religion in which individualisation is broadly undisputed and probably overanalysed, it is to be found in the contemporary Christianity of Western Europe. However, as shall be argued in this paper, in the case of Christianity in contemporary Germany, a model that contrasts individualised religion with institutional religion is too simple. There is a possible mediating position that is the result of special circumstances: the practice of academic Christian theology. Academic theology occupies a special place as a scholarly form of religious self-reflection that is at the same time situated in the university and based on a specific religious creed (Hoffmann et al. 2012; Wissenschaftsrat 2010). This special (and sometimes uneasy) place also means, as I argue, that academic theology is not solely an aspect of either individualised religion or institutional religion. It is for this reason that it may be able to play a mediating role in adequately conceptualising, and thereby alleviating a specific tension between, individualised and institutional religion in German Christianity.

Ә Open Access. ( 2019 Veronika Hoffmann, published by De Gruyter. (c) BY-NC-ND This work is licensed under a Creative Commons Attribution-NonCommercial-NoDerivatives 4.0 International License.

https://doi.org/10.1515/9783110580853-054 
The following is a case study that draws on the specific situation of the two mainstream churches in Germany. While a comparison with other settings, such as free churches in countries without the particularities of the German statechurch law or state churches in Northern Europe, is outside of the scope of this article, it hopes to serve as a preliminary work for such a comparison. ${ }^{1}$ What follows can be read on two different levels at least:

1. On a theological level, this chapter reflects on academic theology in the context of the tensions between institutional and individual religion and on the role of truth claims, individual religious identity, and doubt.

2. The chapter can also be read on a purely descriptive level. From this perspective, it serves as a case study of a religious phenomenon that belongs neither in the category of 'institutional' religion nor in that of 'individual religion'. A stale dichotomy can be avoided and more complex relationships may come to light by showing a possible third category.

First, we must clarify what 'religious individualisation' means in this context. It is not possible to discuss here in full the ongoing debate on this topic (Rüpke and Fuchs 2015; Fuchs 2015; with regard to Christianity in Germany: Gabriel 1996a; Rieger 2009; Wilke 2013). Instead, I will restrict myself to a brief sketch of how religious individualisation will be understood in this paper.

Following Karl Gabriel, I take it that the main feature of religious individualisation is the 'attribution of religion to an individual and his or her biography' (Gabriel 1996b, 12). This definition leads to the following conclusions:

1. Individualised religion is not necessarily religion outside of institutional contexts. Research shows that, in Germany, individualised forms of religion are found within rather than outside of the churches (Bertelsmann 2008; Wilke 2013). Individualised religion is not necessarily a form of religion that abolishes the affiliation to any religious community; rather, it is a certain way that 'individuals interact with religious ideas and institutions' (Rüpke and Fuchs 2015, 324).

2. Individualised religion can be described as 'deviant' religion with respect to the doctrines of the institution, but this is not a necessity or requirement. Quantitative surveys tend to pinpoint religious individualisation in this area, probably because the data can easily be collected - for example, the percentage of members of Christian churches who believe in reincarnation

1 The paper will also refrain from any attempt to predict future developments of the religious field in Germany. Some substantial changes in the course of the next decades are fairly likely. But, in my view, the situation is far too volatile to be in any way predictable. 
(Krüggeler 1993). Deviance from the official creed of the institution is an indication of individualised religion but not a necessary feature.

3. The crucial point lies neither in a disaffiliation from religious institutions nor in individual deviance from official doctrine. The important point is rather the attribution of religion to the individual: understanding the individual (and the individual understanding him- or herself) as his or her own religious authority. The individual may well belong to one of the main churches and even be in complete agreement with that church's teachings. But the ultimate reason for a certain religious form of life is not a social context that imposes it on the individual. Nor is it the sense of obedience to a religious authority nor even a compliance with what universal reason has recognised as 'natural religion' in the spirit of the Enlightenment. The reason lies in the individual and his or her biography - more specifically, the reason is the perceived 'fit' between the individual's self-understanding, his or her personal identity, his or her outlook on the world, and certain religious convictions and practices.

4. This does not necessarily lead to a 'consciously chosen' individual religion, as Peter Berger's 'heretical imperative’ suggests (Berger 1979). As Hans Joas, Charles Taylor, and others have noted, there are many factors at play when it comes to the formation and transformation of religious beliefs and practices, not the least of which are experiences that the individual will perceive as 'given' rather than 'made' (Joas 2014; Taylor 2007, 833). Individual religion is not about choice per se, as a conscious act of selecting something from a menu of religions or compiling one's own 'religion à la carte'. The point is that whatever an individual's religious beliefs and practices may be, they are his or her own in an emphatic sense of the word. They are not based on what religious authorities, the shared positions of a community, or academic consensus tell someone, but on who the person is: on their experiences, their values, and so forth. There is a need for 'personal resonance' (Taylor 2003, 89), as Charles Taylor puts it. This includes the possibility that the individual may not choose at all in matters of religion because religion is just not that important to him or her. And although religious institutions may qualify individual religious positions as 'orthodox' or 'deviant', these are not key questions or categories from the point of view of the individual. When it comes to mixing Christian and non-Christian elements of religion, for example, '[t]hese alternative elements [to Christian religion, V.H.] are not perceived as contrary to the Christian self-understanding but as good and helpful. Authenticity, personal experience and consistency with one's biography are the social place of this form of religion, not some religious creed' (Wilke 2013, 40; Gebhardt et al. 2005). 
The relevant criteria are not the reliability of a religious tradition, the question of universal truth and eternal salvation, or even an overwhelming religious experience. They are (1) the 'authority of the individual' in matters of religion, which refers to the freedom and the responsibility of the individual concerning his or her religion, and (2) the 'fit' of this religion with the individual, including his or her self-understanding and biography, in short, his or her personal identity. As Charles Taylor puts the key idea of our 'age of authenticity': 'the injunction would seem to be: let everyone follow his/her own path of spiritual inspiration. Don't be led off yours by the allegation that it doesn't fit with some orthodoxy' (Taylor 2007, 489).

Taylor's analysis of the age of authenticity is helpful in yet another way: critics of these forms of individual, 'authentic' religion (frequently, but not only, church leaders and theologians) claim that they are shallow, self-centred forms of 'wellness-religion' (for examples, see Gebhardt et al. 2005). According to Taylor, however, although the criticism is justified in some cases, when framed as a sweeping condemnation it overlooks a necessary distinction between 'manner' and 'content' (or 'matter') with regard to religious individualisation (Taylor 2003, 87f.). ${ }^{2}$ The manner is necessarily individualised today: 'The kind of quest which I am invoking here [...] is indeed defined by a kind of autonomous exploration, which is opposed to a simple surrender to authority; and people who engage in this kind of spiritual path are indeed put off by the moralism and code-fetishism which they find in the churches' (Taylor 2007, 509; cf. Wilke 2013, 74). Gebhardt et al. (2005) very aptly speak of the 'self-empowerment of the religious subject'. But this doesn't mean that the content of individualised religion is by definition individualised as well. It is quite possible that the individual's quest leads him or her to forms of spirituality that are not completely self-centred but, rather, oriented toward a higher good and a higher order (Taylor 2003, 82f.). It is this confusion of manner and content that leads to an undue generalisation of individual religion as purely egoistic self-fulfilment.

This idea of a 'religiously self-empowered' individual in pursuit of a spirituality that 'fits' his or her personal identity poses major problems from the point of view of institutional religion. At least, the problem arises within the scope of this 'case study': Christian mainline churches in contemporary Germany. According to Wilke, in some religious traditions, such individual 'tailoring' of religion using different religious ideas and traditions does not lead to tension between the individual and the institution $(2013,76)$. But within Christianity, being a Christian is traditionally linked closely to church membership and questions of universal

2 In his later work, A Secular Age, Taylor 2007 speaks of 'framework' instead of 'manner.' 
truth and eternal salvation. Multiple religious belongings and the combination of ideas from different religious traditions are not acceptable, in theory at least (Zander 2015).

So there seems to be a fundamental incompatibility between these forms of individual and institutional religion. The key problem lies not in differences at the level of belief content (as the standard example of Christians believing in reincarnation suggests) but between, on the one hand, the institutional view of the interconnected nature of religious truth claims, the authority of the church, and institutional belonging and, on the other, the individual view of radical religious self-empowerment. Because this tension is to be found within the institutions, religious self-empowerment and belonging to institutions that are theoretically incompatible in fact go together to a very significant extent. ${ }^{3}$

Now, how is this problem of compatibility addressed - by the individual or by the institution? To a large extent, it isn't addressed at all, either by the institution or by the individual. With respect to the individual, I have already noted that 'deviance' as lack of compatibility with the institution is not a key category. Being at variance with official church teaching is neither a matter of concern nor a matter of liberation or protest (Gebhardt et al. 2005, 146f.). In my view, this is a key difference to earlier versions of 'individualised religion' in European Christianity. The 'religiously self-empowered individual' is (1) not practicing some sort of folk religion. A folk religion typically is not an individual practice and its participants believe themselves to be within the confines of the church community. The individual's self-understanding is (2) not one of being a 'heretic'. Disputes over orthodoxy were traditionally disputes over religious truth claims. The heretic would not claim some sort of individual religion but to be right with regard to everyone sharing the belief in question: if God is not triune then this is a matter of fact that is true for everyone. If the pope has no right to hand out indulgences, then no one can profit from an indulgence, and so forth. As we will see, the question of truth claims and intersubjective justification is one of the main differences between 'religiously empowered individuals' and the self-understanding of theology as an academic discipline.

The perspective of the institution is even more interesting. The problem here is most easily grasped with regard to the Catholic Church. The problem is well known (church leaders are, of course, familiar with surveys such as the 'religion monitors') but it seems that theoretical tools to address it are for the most part lacking. Universal truth claims, the authority of the church teaching, and

3 For a rereading of the classical notion of sacramentality in view of this tension see Hoffmann 2015. 
the requirement for a comprehensive religious praxis of all (baptised) members: these are core principles of the church to which it continues to adhere, although they are seemingly incompatible with individualised religion. Officially, there is no 'Catholicism à la carte'. On the other hand, the Catholic Church has, to a large extent, abandoned any practice of sanctioning or excluding dissenters (the Second Vatican Council explicitly refrained from formulating any anathemas). There are pastoral projects that try to take the tension between the institutional idea of what it means to be Catholic and the individual versions of 'being a religiously self-empowered Catholic' into account. But on the conceptual level, the churches largely resort to an 'as-if' mode: they act as if adhering to the whole apostolic creed and the church teachings, attending mass every Sunday, and so forth can be expected of every member of the church, as if the reasons for noncompliance can be attributed either to unwillingness or ignorance, and as if the remedy therefore is either exhortations or catechesis.

\section{Religious individualisation: gain or loss?}

At first sight, instead of finding a mediating position in the academic realm, the either-or of the individualised-versus-institutional perspective seems to continue there. The contrasting positions of sociologist Ulrich Beck and theologian Ingolf U. Dalferth can serve as examples.

\subsection{Ulrich Beck: 'A God of one's own' for the 'sovereign self'}

Ulrich Beck's view on religious individualisation is clear from the title of his book: A God of One's Own (Beck 2010). As for Wilke, Gebhardt and his co-authors and others, the 'sovereign self' is the new religious 'authority principle' (Beck 2010, 29). Just how important the dichotomy of individual-institutional religion is for Beck becomes clear when he declares secularisation as 'a great gain for religion' (Beck 2010, 24, emphasis in original). 'Secularization does not mean the demise of religion and faith, but instead the development and massive dissemination of a religiosity that is based increasingly on individualization' (Beck 2010, 29). The 'decoupling of (institutional) religion and (subjective) faith' is a key factor. ${ }^{4}$

4 Beck 2010, 26. Beck believes that religious individualisation is part of a larger trend of religious revitalisation. That is highly debatable, for example, if one looks at the data provided by 
What sets Beck's analysis apart from other sociological studies is that his analysis is not purely descriptive. Beck makes a clear plea for everybody's 'own God', especially because the individualising of God is necessary for a more peaceful future of religion. Whereas the 'institutional God' insists on exclusive truth claims, the 'God of the individual' tends to encourage peace and tolerance regarding questions of so-called orthodoxy. According to Beck, if truth claims are ever to be reconciled with peace, this can only be achieved if we take religious truth to be radically subjective: one's own God can be tolerant of the Gods of everybody else.

Beck tries to distinguish his concept of a 'God of one's own' from 'postmodern religiosity'. The latter comprises a 'radical cultural and ethical relativism' (Beck 2010, 134) that is celebrated as liberation from totalitarianism. 'Religious postmodernism is based on the assumption that it is intellectually impossible to choose between "truths". To that extent we can and must make our choices pragmatically - and we do so from the standpoint of "what does me good"' (ibid., 135). Beck's objection to this is that 'the cultural, subjective fluidity of religious convictions undermines the minimum of certainty that individuals require in order to form a personal identity as believers who have to assume responsibility in all aspects of society [...] What keeps the conscious mind alert to the fact that the foundations of a personal religiosity can only be won and defended through public, political intercourse with others?' (ibid., emphasis in original). Instead of a postmodern religiosity, Beck advocates a 'religiosity in the second modernity' that is not based on radical subjectivity but on the 'impurity of cultures': against 'the ideal of purity to be found among the clerical guardians of the truths of institutionalized national churches' (ibid., 140), multiple belongings are possible. By way of example, he refers to what seems to have become the standard example of 'individualised religion': the belief in reincarnation by self-professed Christians (ibid.).

Thus, Beck tries to advocate an individual religion that at the same time has a public dimension to it. Ultimately, however, it remains unclear how he can extract himself from the dichotomy of 'either institutional or individualised'. How, exactly, can he prevent the 'God of one's own' from being no more than a God who ‘does me good'? This paper argues that Beck's model is missing a third perspective between the individual's very own, private God and the religious institutions that claim to have a universal truth. That makes it almost impossible for him to effectively attribute some sort of rational, intersubjectively justifiable dimension to individualised religion.

the 2008 and 2013 Bertelsmann religion monitors. The point here is not Beck's argument as a whole but the way he separates institutional religion and individual spirituality. 


\subsection{Ingolf U. Dalferth: 'I determine what God is' as 'cafeteria religion'}

Can academic theology provide this third perspective? It is important to note that while there is no sharp boundary between theologically trained and untrained individuals - probably every form of belief implies some sort of 'theology' -, the distinction between individual religion and academic theology in our case can be made clearly. This is in part due to the specifics of the German situation mentioned above: the academic discipline of theology is, on the one hand, connected to a specific religious denomination but, on the other hand, committed to the rules of the academic discourse, namely an argumentative approach in the context of public discourse. Both features do not apply to the 'religiously empowered self'.

At first glance, it seems that although theology is not structurally to be identified with the magisterium - and is very adamant about its academic freedom -, with respect to the critical view of individual religion, the mainstream of Christian theology sides with the institutional view. Ingolf U. Dalferth's criticism of what he calls ‘cafeteria religion' can serve as a case in point (Dalferth 2000). He argues that if 'I determine what God is', individualised religion is incapable - and unwilling - of rational justification: 'No one asks whether what is determined this way is really God and whether God is really this way. These questions play no role because they are not thought to have any answer that would be more than a new (or old) mixture of opinions. In matters of religion and faith, public opinion now seems to recognize, at most, questions of taste' (ibid., 8). Theology, in contrast, although as a self-reflection of religion speaking from the perspective of the participant rather than the observer, aims at rational self-reflection and thereby at the ability to account for its position in public discourses. Its critical distance but not separation - from faith makes it possible for theology to explore the difference between the belief in God and the reality of God, although the reality of God is never accessible from the point of view of an observer. And the reality of God is the reference point, according to Dalferth: 'The faithful do not subscribe to the principle "We determine what God is", but rather to the principle "God determines what we are". They thus determine God as they are determined by his reality. This, at any rate is the claim by which they are to be measured and it is the task of theology to do so critically. The truth of faith is decided by God's reality' (ibid., 18).

The Barthian heritage is of course clearly perceivable in this argument. More interestingly, Dalferth, as a Protestant, is in no danger of arguing too loudly with the authority of the church. He doesn't claim that theology has definitive answers, either: 


\begin{abstract}
This does not mean, that we - as individuals or as a community - must consider our own understanding of God infallible or absolute. What Christians believe is not true because they believe it. They distinguish between God and the understanding of God, between truth and the practice of faith, because they seek to align themselves with God's reality. In this way, the fundamental capacity for and obligation to self-criticism is built into the Christian faith itself. To this belongs that we refer to others in our own practice of faith, communicate with them, and thus create relative public spheres in which there is room for comparison, conflict, correction, deepening, or the combination of different conceptions of God.
\end{abstract}

(Dalferth 2000, 19).

But truth claims and public accountability are the standards of Christian religion, not a 'fit' to personal wishes and spiritual needs. As Dalferth notes, 'Precisely here lies the ineradicable contrast to the current culture of religious tinkering. Because they confess that they live out of the perception of God's effective presence, Christians are obliged to resist the contemporary tendencies toward the privatization of faith, subjectivist mysticism, and the dissolution of religion into psycho-technical media of self-discovery' (ibid., 22f.).

Thus, the authority that is overthrown by the authority of the 'self-empowered religious individual' is not to be understood too narrowly as the authority of the ecclesial magisterium. It may as well be the authority of Scripture or, as in Dalferth's case, the perceived authority of God himself (usually thought of as mediated through the Scriptures and, in some cases, through religious experience). The common denominator of those concepts is that the authority to 'determine what God is' lies not with the individual but with an 'outside authority.' This does not mean that the individual has to follow this authority blindly. As we have seen, Dalferth argues strongly in favour of critical reflection and public discourse. But it means that faith is discovered, taken on, accepted, or appropriated, not made or compiled.

\title{
2.3 Academic theology: critic of religious individualisation by default?
}

Although positions vary, of course, and not every theologian would agree with Dalferth's arguments in every respect, assessments of individual religion such as that offered by Dalferth are quite prevalent in Christian theology. There is a considerable amount of scepticism concerning common forms of individualised religion (Gebhardt et al. 2005, 139). Critical reviews of Beck's God of One's Own support this impression. Wilhelm Eppler, for example, argues that a 'sovereign self' that looks at religion in a purely utilitarian fashion disregards the truth 
claims inherent in the Christian faith as revealed religion (Eppler 2009). And Gregor Maria Hoff remarks that any form of critical reflection on religion - the principal task of Christian theology - is made impossible if everybody believes only in his or her own God (Hoff 2008). Like Dalferth, Hoff highlights as the key problem the lack of any 'outside' dimension of individualised religion. The religious self's own God is a completely internal one, a God that 'looks confusingly similar to the self' (Hoff 2008).

Individualised religion seems to be inherently problematic not only from the perspective of religious institutions but - albeit for other reasons - from the perspective of Christian theology as well. But this paper argues that, on a closer look, theology can provide theoretical tools to help understand individualised religion in a more nuanced way and without $a$ priori questioning the truth claims of the Christian religion. In this way, the dichotomy of individualised versus institutional religion can be transformed into a tension that can be handled instead of ignored. For the most part, these tools are already at hand but have not yet been applied systematically to the question of individualised religion and its relation to religious institutions.

\section{Conceptualising individual religion and its tension with institutional religion from a theological point of view}

There are at least two lines of argument in current theology that take the view of the individual into account in some way. Both provide helpful insights but they also have their shortcomings, so it will be necessary to explore a third line of approach as well. In each case, how the issue of religious doubt is treated will serve as a test case for the relationship between questions of truth, authority, and individual appropriateness. Although an open approach toward doubt is not in itself a sign of individualised religion, the ways in which religious doubt is understood nevertheless reveal something about how individual faith is conceptualised in relation to institutional authority and intersubjective truth claims. $^{5}$

5 For a more detailed reflection on the emergence of new perspectives on doubt in Christian theology, see Hoffmann 2017. 


\subsection{Rational justification of faith}

The first approach has, in fact, already been introduced into our discussion by Dalferth's arguments. Theology aims for a rational justification of faith and thereby moves away from any idea of unquestioned obedience to Scripture, church teaching, and the like. Without rational insight, there can be no public accountability, and rational insight cannot be prescribed. The individual himself or herself may and must take on the responsibility for what he or she believes. So, in a sense, critical self-reflection of religion itself shifts the emphasis toward the individual. However, at the same time, the reason to which rational argumentation refers is not individual, in the sense of relying on a personal fit or a biographical dimension, but is, rather, universal, as rationality is generally understood to be. The reflective process is not aimed at the meaningfulness for the individual but at intersubjective accountability.

This move toward the individual but not, as it were, to the personal level is reflected in the role of doubt - whether it concerns certain key beliefs or practices or the religious option as a whole. Traditionally, because faith is closely linked to truth and salvation, the more certain it is, the better. Doubt is an unwanted and potentially dangerous phenomenon. But if rational insight is one of the key features of individual faith, doubt may play an important role in the process of clarifying one's position. Many theologians would argue that, at least from a rational point of view, faith never becomes unquestionably evident. It follows from this that doubt might even be an unavoidable presence, a constant factor in the 'conflict of [religious and nonreligious] interpretations' ${ }^{6}$ On the other hand, this form of doubt does not stem from 'personal resonance' but from rational justification, an intellectual exercise, it is true, but not necessarily a markedly individual act. In principle, and at least in the context of the same cultural and intellectual heritage, a good argument would be a good argument for everyone.

\subsection{Faith development}

The biographical dimension of faith is more evident in the second line of approach: theories of faith development, such as James Fowler's 'stages of faith' (Fowler 1989). Here, individual faith is closely connected with biographical processes. It develops essentially in the context of the personal development from

6 For a prominent example of a theology based on this idea (the term 'conflict of interpretations' is derived from Paul Ricœur, but adapted to the theological setting), see Werbick 2005. 
childhood to adolescence to adulthood. It is not necessary to look in depth at theories of faith development to see that a fundamental issue already arises in the concept of a 'development' (usually in one direction, with possible stagnation but no relapses) towards a 'mature state' of faith. Such a teleological understanding of 'faith development' tends to restrict the individualisation of religion to individual ways of finally reaching a predefined goal. ${ }^{7}$ Of course, a development of identity can be assumed in children and adolescents and that their faith also develops in this context. But both become problematic when they assume that although some may climb further up the ladder than others, (1) there is a place for everybody to stop, and (2) there is no going back, no climbing down the ladder again. ${ }^{8}$ Hartmut Rosa has maintained that, for many today, personal identity is no longer something they 'develop', 'find', or 'achieve' at some point in their lives but, rather, an ongoing process (Rosa 2002). The same applies to the religious dimension of that identity.

Thus, although faith development theories provide a helpful connection between biographically shaped individuality and religion, there are some heavy constraints to this connection. Our 'test case' - doubt - also points in this direction. In the context of faith development, doubt can easily be seen as an integral part of this development, marking the transition from one stage of faith to another. But its function tends to be limited to that of a catalyst for growth. The direction in which it will lead (ultimately, 'higher up') seems to be clear from the outset.

\subsection{The processual character of religious identities and the role of faith and doubt}

These - and possibly other - approaches pave the way for a concept of faith that pays more attention to the dimension of the individual. But in and of themselves, they don't lead far enough to overcome our individual-institutional dichotomy. If theology wants to find a conceptual way to transform the dichotomy between individual and institutional religion into a tension, it needs to link faith and personal identity more closely. Two aspects are of particular relevance:

7 It is important to note that this does not imply that the later stages are 'better': Fowler and Dell 2006, 40.

8 Fowler speaks of the possibility of a 'recapitulation' of earlier stages of faith, but that is not a real relapse but a new working-through of an earlier stage that overcomes earlier blocks or unresolved issues (Fowler 1989, 289ff.). 
1. What Taylor calls 'personal resonance' is mandatory. That a faith is said to be true or to lead to salvation (or both) is no longer a sufficient reason to engage in it, as long as it does not resonate with the individual. At the same time, Taylor's distinction between the 'manner' and 'matter' of individualisation will help to counter the criticism of Dalferth and others that religious individualisation will lead to a completely 'subjectivised' religion.

2. Personal identity is to be seen more as an ongoing process, not as a sequence of developments that reaches its final destination in a 'maturity of adulthood' and that applies equally to its religious dimension. A once-and-for-all-stability may not even be the ideal anymore. Instead, the aim is an always-to-berediscovered 'fit' of all the elements of an ever-changing personal identity in ever-changing contexts. Applied to religion, it is not the stability of a definitive, doubtless faith that is looked for, but a personal faith that changes as the personal identity changes - without this identity 'growing' to a 'definite' or 'mature' state. Gebhardt et al. speak of religious 'wanderers' (instead of 'pilgrims', who are also on the way but are on their way to a clearly defined destination). Taylor takes up the image of being religiously 'underway' when he outlines 'authentic spirituality' as not aiming for a 'position' (of religious certainty, of attained truth, etc.) but as a spirituality of personal 'quest': 'I have to discover my route to wholeness and spiritual depth. The focus is on the individual, and on his/her experience. Spirituality must speak to this experience. The basic mode of spiritual life is thus the quest' (Taylor 2007, 507f.).

In this setting, doubt, like faith, can be seen as a companion during the whole process of identity formation and re-formation, being affected by, causing, alleviating, or speeding up the mechanisms involved. Doubt can also be understood as a signal that the 'fit' between the individual's overall self-understanding and his or her religious beliefs and practices is lost. It therefore can be a catalyst but also a danger, a challenge, or a permanent feature of one's religious identity. What is not the key factor here is what is frequently on the forefront of accounts of religious individualisation: a 'deviance' of the individual's religious beliefs and practices from those of the institution - perhaps even a deviance that makes a point of being deviant. The notion of doubt shows that the process component of religious individualisation connected to identity processes refers not only to an individual appropriation of or deviation from institutionalised religion but also to the process character of individual religion itself: the doubting individual can question religious positions or practices of communities as well as his or her own religious perspective.

So much for doing justice to the individual side of our 'dichotomy to be transformed into a tension'. What about what has been subsumed under the heading 
of 'institutional': the role of the churches themselves, as well as questions of truth and rationality that have an inherently intersubjective dimension and, consequently, are in danger of marginalisation in the context of 'one's own God'? Critics aren't wrong to claim that if 'I determine what God is' in a sense that excludes all rational justification or reference to already established religious reflection then it is highly questionable if the thus-determined God is anything more than a projection of my wishes, needs, and ideals. As noted earlier, Taylor's distinction between the 'manner' and the 'matter' of what he calls 'subjectivation' can be used to maintain the tension here instead of resolving it in any one direction. Taylor contends that it is not only possible but necessary to orient one's identity toward perspectives or values that don't begin and end within the individual: 'I can define my identity only against the background of things that matter. But to bracket out history, nature, society, the demands of solidarity, everything but what I find in myself, would be to eliminate all candidates for what matters' (Taylor 2003, 40). A similar argument is made by Rosa; the 'turning inward' of the individual only works as long as it is not complete: 'As long as a subject is able to ontologise any part of his or her identity (more discovering than choosing it, as it were), and defends this part against all opposition, a highly individualised identity can be developed, maintained and articulated' (Rosa 2002, 290, emphasis in original). Identity problems don't arise because the individual fails to find definite answers to all the questions he or she asks in the course of this development. The identity enters into a crisis when those questions can't even be asked anymore because a radicalised self-reference no longer accepts any values as more than arbitrary choices - a subjectivation of manner and content, as Taylor would call it.

From a theological point of view, this form of connecting individual religion and personal identity allows for a subtler theological understanding of religious individualisation. There is no need to reject it $a$ priori, implying that all individualisation equals some sort of self-sufficient, self-centred 'wellness-religion'. Nor has theology to refrain from any critical assessment for the sake of 'personal resonance', for example, with regard to the possibly projective character of 'one's own God'.

\section{Conclusions and consequences}

I have argued that theology can occupy something of a mediating position between individual and institutional religion. Usually, individual religion tends to ignore or outright reject the claims of truth and authority that institutional religion raises, whereas institutional religion tends to be critical of 'completely subjective' individualised religion. The conceptual possibilities for the integration of 
individual perspectives into the basic orientation of the main Christian churches in Germany are still limited. Theology offers some initial approaches towards the connecting of individual and institutional perspectives that can be used as starting points for a 'mediation' between the two. A basis for further development is the notion that faith and doubt are intimately connected with the shaping and reshaping of personal identity, but it does not follow that one has to completely abandon claims of intersubjective rationality and the possibility for truth. Religious beliefs and practices depend on a 'personal resonance' from the side of the individual, and the distinction between 'manner' and 'matter' of individualisation makes an 'outside grounding' of this personal resonance conceivable.

This by no means implies that the tension between individual and institutional religion can easily be resolved. One could rather argue that it can in this way be described more clearly and therefore recognised as a tension. Theology has to play its part as a medium for critical self-reflection of religion in both directions. Individual religion must, for example, face questions about the projective character of a 'God of one's own'. Institutional religion has yet to fully realise that (1) 'faith' can no longer be conceived of as some objective 'state' defined by church authority that is to be attained and maintained by church members, and that (2) 'personal resonance' and a connectedness with personal identity must shape any contemporary theology of faith (and doubt).

What might be the consequences for both sides of the 'tension'? Here one can only speculate. On the side of individual religion, the possible effects of such a theological approach are particularly difficult to determine. They will depend on, among other factors, a certain willingness of the individual to reflect on and rationally question his or her religious beliefs and practices (otherwise, the concept of 'doubt' is also difficult to apply).

Possible consequences may more easily be envisaged on the side of the institution. The connection of faith, doubt, and identity accounts for individualised religion within a theological framework that is compatible with the core beliefs of the institution. Therefore, it can offer an interpretive approach to the tension between institutional religion and individualised religion within the institution. The individual approaches to, appropriations of, and deviances from the institutional religion would no longer have to be handled in an 'as-if mode'. Instead, they could be interpreted as integral parts of the processual character of lived individual religion. This might be characterised as some sort of 'reinstitutionalisation' of individual religion - if the term is used in line with the overall thrust of the present paper, that is, as referring more to discursive changes than to empirical data. Perhaps a term such as 'institutional integration of individualised religion' would be more appropriate. 


\section{References}

Beck, Ulrich. 2010. A God of One's Own. Religion's Capacity for Peace and Potential for Violence. Cambridge: Polity.

Berger, Peter L. 1979. The Heretical Imperative. Contemporary Possibilities of Religious Affirmation. Garden City, NY: Anchor Press.

Bertelsmann Stiftung (ed.). 2008. Religionsmonitor. Gütersloh: Gütersloher Verlagshaus.

Dalferth, Ingolf U. 2000. “"I Determine What God Is!” Theology in the Age of "Cafeteria Religion”, Theology Today 57. 5-23.

Eppler, Wilhelm. 2009. 'Religion mit Risiken und Nebenwirkungen. Ulrich Beck zum Verhältnis von Religion, Gewalt und Individualisierung', Theologische Beiträge 40.133-8.

Fowler, James W. $1989^{18}$. Stages of Faith: the psychology of human development and the quest for meaning. San Francisco: Harper \& Row.

Fowler, James W. and Mary Lynn Dell. 2006. 'Stages of Faith from Infancy through Adolescence: Reflections on Three Decades of Faith Development Theory'. In The Handbook of Spiritual Development in Childhood and Adolescence, ed. Eugene C. Roehlkepartain et al., Thousand Oaks, California/London: SAGE. 34-45.

Fuchs, Martin. 2015. 'Processes of Religious Individualisation. Stocktaking and Issues for the future', Religion 45. 330-43.

Gabriel, Karl (ed.). 1996a. Religiöse Individualisierung oder Säkularisierung: Biographie und Gruppe als Bezugspunkte moderner Religiosität. Gütersloh: Kaiser.

Gabriel, Karl. 1996b. 'Einleitung'. In Religiöse Individualisierung oder Säkularisierung: Biographie und Gruppe als Bezugspunkte moderner Religiosität, ed. idem, Gütersloh: Kaiser. 9-13.

Gebhardt, Winfried, Martin Engelbrech and Christoph Bochinger. 2005. 'Die Selbstermächtigung des religiösen Subjekts. Der "spirituelle Wanderer” als Idealtypus spätmoderner Religiosität', Zeitschrift für Religionswissenschaft 13.133- 152.

Hoff, Gregor M. 2008. 'Im Feuer des Gottesmanagements', FAZ 07.07.2008 (http://www.faz.net/ aktuell/feuilleton/buecher/rezensionen/sachbuch/religionundwahrheitimfegefeuerdesgottesmanagements1624202.html, accessed 5-2-2015).

Hoffmann, Veronika. 2015. 'Sakramentalität unter dem Vorzeichen des religiösen Pluralismus', Liturgisches Jahrbuch 65. 155-71.

Hoffmann, Veronika. 2017. 'Glaube, Zweifel und Identität in einem “säkularen Zeitalter” (Ch. Taylor)'. In Nachdenken über den Zweifel. Theologische Perspektiven, ed. idem, Ostfildern: Matthias-Grünewald-Verlag.

Hoffmann, Veronika, Georg M. Kleemann and Stefan Orth (eds.). 2012. Unter Hochspannung. Die Theologie und ihre Kontexte. Freiburg/Basel/Wien: Herder.

Joas, Hans. 2014. Faith as an Option. Possible Futures for Christianity. Stanford: Stanford University Press.

Krüggeler, Michael. 1993. 'Inseln der Seligen. Religiöse Orientierung in der Schweiz'. In Jede(r) ein Sonderfall? Religion in der Schweiz. Ergebnisse einer Repräsentativbefragung, eds. Alfred Dubach and Claude Bovay. Zürich: NZN- Buchverlag. 93-132.

Rieger, Martin (ed.). 2009. What the World Believes. Analyses and Commentary on the Religion Monitor 2008. Gütersloh: Verlag Bertelsmann Stiftung.

Rosa, Hartmut. 2002. 'Zwischen Selbstthematisierungszwang und Artikulationsnot? Situative Identität als Fluchtpunkt von Individualisierung und Beschleunigung'. In Transitorische 
Identität. Der Prozesscharakter des modernen Selbst, eds. Jürgen Straub and Joachim Renn, Frankfurt am Main/New York: Campus Verlag. 267-302.

Rüpke, Jörg and Martin Fuchs. 2015. 'Religious Individualisation in Historical Perspective', Religion 45. 323-9.

Taylor, Charles $2003^{11}$. The Ethics of Authenticity. Cambridge, Mass.: Harvard University Press. Taylor, Charles 2007. A Secular Age. Cambridge, Mass: Belknap Press of Harvard University Press.

Werbick, Jürgen. $2005^{3}$. Den Glauben verantworten. Eine Fundamentaltheologie. Freiburg/ Basel/Wien: Herder.

Wilke, Annette. 2013. 'Säkularisierung oder Individualisierung von Religion? Theorien und empirische Befunde', Zeitschrift für Religionswissenschaft 21. 29-76.

Wissenschaftsrat 2010. Empfehlungen zur Weiterentwicklung von Theologien und religionsbezogenen Wissenschaften an deutschen Hochschulen. Köln. (https://www.wissenschaftsrat.de/download/archiv/9678-10.pdf, accessed 7-16-2018)

Zander, Helmut. 2015. 'Europäische' Religionsgeschichte: religiöse Zugehörigkeit durch Entscheidung - Konsequenzen im interkulturellen Vergleich. Berlin/Boston: De Gruyter De Gruyter Oldenbourg. 
